\title{
$\angle$ Research Square \\ Rainfall distribution and tea production in Bangladesh: Socio-economic impact analysis
}

Md. Mizanur Rahman ( $\nabla$ mizan_peroj@yahoo.com )

ICT Division, Government of the People's Republic of Bangladesh

\section{Research Article}

Keywords: Rainfall, cost of production, the emergence of pest, daily income, job market

Posted Date: December 15th, 2021

DOI: https://doi.org/10.21203/rs.3.rs-1172844/v1

License: (a) (i) This work is licensed under a Creative Commons Attribution 4.0 International License. Read Full License 


\section{Abstract}

The study aimed to assess the present pattern of tea production and the impacts of rainfall patterns on tea yield and made tea quality. The cost of production and profit-loss were examined to link with rainfall distribution. Likewise, the daily income of permanent workers, the job market of the contractual workers, and the workers' associated welfare were critically analyzed to understand the social impact. The Rangpur division showed an incremental dryness; in contrast, the Sy/het division showed a steady pattern with a high frequency of continuous heavy rainfall. The rainfall pattern of the Chottogram division was highly unpredictable and oscillated. Long spell drought and heavy showers followed by flash floods affect tea yield. According to respondents' perception, the rainfall pattern showed changing behaviours that are not favourable for tea production. The emergence of new pests and deterioration of soil characteristics were reported. Bangladesh enjoyed the most pleasant weather for tea production in 2019. The cost of production increased with the adverse weather, which increases the loss for the growers. Profit loss of growers is a determinant of the welfare of the workers impacting their livelihoods. The organic tea garden is not affected by climatic events. Consequently, the socio-economic conditions of the organic garden are safeguarded. Hence, the study recommends following organic farming to cope with climate change. Differently, it was reported that the intermediaries' hegemony in the market chain is more problematic than climate change. Policy initiatives are warranted to correct the market and to establish growers and consumers' rights.

\section{Introduction}

Tea, a rainfed plant, grows across a wide range of climates and soils. The tea ecosystem comprises the tea plant, shade trees, the associated crops, and abiotic elements. Tea is a cash crop in Bangladesh, contributing a significant role in our economy and food security. Bangladesh obtained the 8th position in the production area, the 10th position in production, and the 12th position in exporting (ITC, 2020). In 2020, 167 tea estates in Bangladesh produced 86.39 million kg made tea, out of which 2.17 million $\mathrm{kg}$ were exported (BTB, 2021). Tea production largely depends on micro-climatic conditions, notably rainfall. Bangladesh is facing extreme weather and climate events for the last decades. The country encounters extreme weather events like circadian drought, prolonged precipitation, and late winter (Basher et al., 2018; Mojid et al., 2015). Bangladesh is one of the worst hits for climate change due to its geographical location is (Mishra et al., 2019). Tea is considered one of the most vulnerable crops for climate change (Ochieng et al., 2016). Tea leaf production is highly sensitive to both biotic and abiotic stressors (Cheruiyot et al. 2010). The drought drastically affects its production (Niinemets, 2015). In recent times, the rainfall distribution in tea-producing areas shows a remarkable variation (Dutta, 2014). The monsoonal rainfall affects the yield and the product's quality (Wijeratne et al., 2007). The various study showed that the drought alters the metabolites' concentration (Ahmed et al., 2014; Cai et al., 2013; Eric et al., 2019; Kfoury et al., 2018; Han et al. 2017). Few studies measured the rainfall's impact on the tea yield of a single or few tea gardens of the Sylhet district (Islam et al., 2021; Rahman et al., 2017; Ali et al., 
2014). A study including all tea-producing areas will help better understand the change in rainfall distribution area-wise and the effect on tea yield and the quality of the products.

Chang and Brattlof (2015) reported that climate change has socio-economic impacts on tea production in India. Additional expenses to cope with the challenges cannot be balanced by increasing tea prices. In the market economy, the consumers buy the products by judging the price. Roy (2013) revealed that rainfall has a relationship with rural socio-economic conditions. Rain affects the total agricultural and industrial development of a country. The monsoonal rainfall influences local agricultural productivity and employment generations. In turn, the amount of rainfall determines the availability of water to meet various demands for agriculture, industry, hydroelectricity, and other human activities. Due to the declining rainfall volume in Bangladesh, agricultural crop production decreases (Roy, 2013). With the decline of rainfall, Sylhet districts showed lower agricultural production. Hence, an evaluation of tea's yield and rainfall trend will help predict rainfall variability, changes in the seasonal pattern, and effect on this cash crop's production.

Some tea gardens encounter various problems like erosion of topsoil due to uncharacteristic heavy rainfall patterns, which harms production, increased use of fertilizers to maintain soil fertility, and increased pesticide usage, particularly during the dry season (Chang and Brattlof, 2015). Notably, there are several uncertainties due to climate change impacts that are not yet fully understood but could potentially affect future production levels, employment, and welfare of the growers and workers. These include the frequency of natural disasters, the proliferation of certain pests and diseases, and higher infrastructure costs. Quio et al. (2018) reported that tea cultivation is not only for cash earning but also plays a multidimensional benefit for both farmers and industrialists. Differently, organic agriculture has the potential to provide improved livelihood opportunities, increased income, and social benefits for resource-poor small-scale farmers. A comparative analysis between conventional tea cultivation and organic farming can help understand the importance of organic farming to adapt to climate change by ensuring growers' and workers' interests.

Therefore, there is a need to develop an integrated adaptive measure to cope with the changing climate by linking climatic impact with social impact. The fundamental unity of the knowledge ranging from pure science to social science is indispensable for adopting a better policy. Therefore, the study attempts to assess the present pattern of tea production and the impacts of rainfall variations on tea yield. Both quantity and quality of the yield are interconnected to the cost of production and loss-profit. The study also strived to assess the production cost associated with rainfall patterns. It is essential to examine how the worker's welfare in terms of daily income, overtime works, job market, and other facilities are affected by the production. Finally, the study came up with solutions to cope with climate change.

\section{Conceptual Framework}

Socio-economic activity persuades climate change; contrarily, climatic variation affects socio-economic activity. Both have a substantial interaction. Climate change impacts the gross domestic product and 
labour productivity (Matsumoto, 2019). Changing climatic elements causes the reduction of natural resources like water, which affects the people's socio-economic livelihood and health. Agriculture suffers from low productivity and yield, the prevalence of diseases, which results in increased poverty (AdjeiMensah and Kusimi, 2020). The impact assessment of climate should consider two interrelated processes: socio-economic impact and climate change. The change in socio-economic activities has not been sufficiently incorporated in impact assessment (Berkhout et al. 2002). Hence, the study integrated the difference in socio-economic conditions systems to assess the impact of climate change.

Over $80 \%$ of the whole population of Bangladesh lives in the rural sectors. As the deltaic floodplain, Bangladesh is highly sensitive to climatic variation. The predominant agricultural economy is interconnected with the monsoonal characteristics, notably the pattern of wet and dry seasons (Ericksen et al., 1996). The changes in climatic variables have severe implications for the local economy and community' welfare. Changes in tea yields and quality of made tea may negatively impact the economy and gardeners' and workers' livelihoods (Ahmed et al., 2018). The study explored this theme. The ecology also depends on much anthropogenic and non-anthropogenic perturbation, which impact together. The study stressed only rainfall distribution as it determines tea production primarily (Wijeratne 1996). Ironically, the tea gardeners do not keep data on maximum temperature, minimum temperature, mean temperature, humidity, day length, light intensity, dew points, soil temperature, soil chemistry and physics, slope, organic matter contents, etc. The study aimed to assess the rainfall's impact on yield and other socio-economic impacts (Figure 1). The main relationships among rainfall, tea yield, and workers' welfare were embraced as climate change's socio-economic impact. This theme was explored through four main questions: What is the trend of tea yield in Bangladesh? How does the rainfall pattern affect the yield and quality of the product? How are the gardeners affected in terms of cost-benefit analysis? What are the consequences on the workers? And what should be the remedies?

\section{Methodological Framework}

The study collected both primary and secondary data for the period from November 2020 to March 2021. The existing literature related to the socio-economic impact of climate change was studied to understand the broader picture of the collected data and develop a theoretical framework for this paper. A stepwise systematical research approach was used for a better outcome (Figure 2).

\subsection{Assessing the trend of rainfall and tea yield}

Ten tea gardens were taken from three tea-producing administrative divisions: Sy/het, Chattogram, and Rangpur, which covered 06 administrative districts, namely Sylhet, Moulovibazar, Hobiganj, Panchagarh, Chottogram, and Rangamati. The recorded data on monthly rainfall and tea yield from 2010 to 2020 were collected from each garden. In addition, secondary data on the national yearly tea production of the same duration were collected from Bangladesh Tea Board. For a broader understanding, tea production time in India, Sri Lanka, and China was used from the source of statistica dot com.

\subsection{Relating annual rainfall and yield}


The annual rainfall was defined as the independent variable and tea yield as the dependent. Pearson correlation coefficient (PCC) determined the nature of the relationship. Eleven years' data (2010-2020) of 10 gardens were used in this calculation. In addition, a simple descriptive analysis was followed to correlate yield with rainfall patterns.

\subsection{Other economic impact assessment}

A comparative assessment of the cost of production and profit/loss per hectare area between the years 2019 and 2020 was done based on the tea gardens' data. A focus group discussion was held at each garden to understand the changing behaviour of rainfall patterns and associated problems like the emergence of new pests and their effects on the products' quality.

\subsection{Social impact assessment}

A total number of 30 workers were selected purposively from each garden. Among them, 15 were permanent workers, and the rest was temporary or contractual worker. They were interviewed with a semistructured questionnaire focusing on daily income, monthly employment of the temporary workers, payment regularities, housing facilities, and sanitation status. Based on the collected data, a comparative assessment between the years 2019 and 2020 was accomplished.

\subsection{Assessing extra-climatic problems}

The study analyzed the key actors of tea markets and assessed the profit/loss of the intermediaries based on the data collected from FGDs. In addition, a consultation workshop was held in Chittagong, where the tea growers and representatives from the warehouse, brokers, and buyers were present. Telephonic interviews were done with the senior management of the Bangladesh Tea Board.

\section{Results And Discussion}

\subsection{Yield (made tea) trend from 2010 to 2020}

It was found that the average yield in the study area ranged from $1015 \mathrm{~kg} / \mathrm{ha}$ to $1466 \mathrm{~kg} / \mathrm{ha}$. The highest yield was counted in 2019, followed by 2016 and 2020. Contrastingly the lowest yield was observed in 2011. The annual production per hectare area remained almost symmetrical in 2010-12, 2014-15, 201718 , and 2020 . The trend continues on an upper path.

Among the tea-producing administrative divisions, Chottogram exhibited a highly choppy trend of yield. The highest yield was enumerated in 2010, and the lowest in 2020. Despite oscillation, Sylhet division gradually increased its yield. Rangpur division maintained a gentle uptrend, which maximized its yield during 2014-2017.

The tea yield trend per hectare in the whole study area is mirrored by the national production trend (Figure). The highest annual national production ( 96.07 million $\mathrm{kg}$ ) was recorded in 2019 , followed by 
2020. The lowest national production (59.13 million $\mathrm{kg}$ ) was found in 2011. In the rest years, the annual national output ranged from 60.04-85.05 million kilograms.

Bangladesh showed an increasing production trend from 2016, and in 2020 the production increased by 1.40 times compared to 2010 . The country could not maintain the consistency of 2019's record in 2020. Among other major tea-producing countries of Asia, China doubled its production from 2010 to 2020. India showed a consistent and gradual increase from 2010 to 2020. Tea production in India was 1.5 times in 2020, considering 2010 as a baseline. Sri Lanka exhibited almost a flat trend in annual production.

\subsection{Impact of rainfall on tea yield}

\subsubsection{Rainfall trend from 2010 to 2020}

By taking the monthly average rainfall in the study area from 2010-2020, the highest rainfall was recorded in June, followed by July, August, May, and September. The average rain varied considerably from year to year. The highest rainfall was enumerated in July 2019 and 2020 . The year 2014 faced 03 months-long drought conditions.

The Sylhet division showed a symmetrical average monthly rainfall pattern. In July 2020, this division enjoyed heavy pouring (1059 mm), the monthly highest record from 2010 to 2020 considering the entire study area. One week-long continuous overweighted downpour caused flooding in the tea gardens. Likewise, 2014 faced 03 months-long droughts. A total number of 06 months was counted from 20102020 in this division. Except that drought is not a problem there.

Table 1: Monthly rainfall pattern and yield during 2010-2020 in Sy/het division

\begin{tabular}{|c|c|c|c|c|c|c|c|c|c|c|c|c|c|c|}
\hline \multirow[t]{2}{*}{ Year } & \multicolumn{13}{|c|}{ Rainfall (mm) } & \multirow{2}{*}{$\begin{array}{l}\text { Yield } \\
\text { ha/kg }\end{array}$} \\
\hline & Jan & Feb & Mar & Apr & May & Jun & Jul & Aug & Sept & Oct & Nov & Dec & $\Sigma$ & \\
\hline 2010 & 0 & 4 & 269 & 648 & 569 & 751 & 499 & 499 & 574 & 165 & 0 & 31 & 4010 & 1094 \\
\hline 2011 & 14 & 11 & 131 & 227 & 544 & 522 & 545 & 414 & 333 & 130 & 13 & 18 & 2902 & 1109 \\
\hline 2012 & 11 & 13 & 141 & 311 & 358 & 772 & 496 & 460 & 235 & 116 & 15 & 2 & 2930 & 1114 \\
\hline 2013 & 3 & 16 & 92 & 342 & 602 & 714 & 480 & 465 & 275 & 240 & 44 & 8 & 3282 & 1055 \\
\hline 2014 & 0 & 21 & 52 & 141 & 646 & 458 & 385 & 463 & 480 & 174 & 0 & 0 & 2819 & 1177 \\
\hline 2015 & 5 & 32 & 42 & 239 & 498 & 503 & 429 & 623 & 551 & 58 & 10 & 2 & 2994 & 1135 \\
\hline 2016 & 13 & 45 & 116 & 524 & 566 & 582 & 463 & 512 & 423 & 118 & 36 & 1 & 3397 & 1444 \\
\hline 2017 & 10 & 56 & 288 & 747 & 475 & 713 & 490 & 570 & 416 & 226 & 56 & 54 & 4101 & 1136 \\
\hline 2018 & 9 & 61 & 282 & 430 & 641 & 883 & 612 & 709 & 461 & 214 & 8 & 66 & 4375 & 1168 \\
\hline 2019 & 4 & 40 & 100 & 243 & 528 & 790 & 829 & 441 & 341 & 181 & 22 & 11 & 3531 & 1556 \\
\hline 2020 & 11 & 24 & 49 & 281 & 615 & 994 & 1059 & 419 & 530 & 288 & 16 & 0 & 4288 & 1356 \\
\hline
\end{tabular}

The Chottogram division showed a little bit asymmetrical average monthly rainfall pattern. The monthly as well as yearly rainfall average is highly fluctuating. The month of June received the highest average rainfall during July, August, and September during 2011-2020. The year 2013 faced an almost 05 months long consecutive drought. In 2014, the division yielded less because continuous heavy pouring in June 
caused a short-lived flash flood, and the month of July was comparatively drier. In 2010 and 2019, only January month was rainless. The year 2020 experienced two spells of short-lived drought: FebruaryMarch and December. The rest years encountered more than 01 month-long dry season.

Table 2: Monthly rainfall pattern and yield during 2010-2020 in Chottogram division

\begin{tabular}{|c|c|c|c|c|c|c|c|c|c|c|c|c|c|c|}
\hline \multirow[t]{2}{*}{ Year } & \multicolumn{13}{|c|}{ Rainfall (mm) } & \multirow{2}{*}{$\begin{array}{l}\text { Yield } \\
\text { ha/kg }\end{array}$} \\
\hline & Jan & Feb & Mar & Apr & May & Jun & Jul & Aug & Sept & Oct & Nov & Dec & $\Sigma$ & \\
\hline 2010 & 0 & 7 & 70 & 39 & 273 & 658 & 311 & 344 & 156 & 192 & 24 & 15 & 2089 & 1437 \\
\hline 2011 & 0 & 13 & 39 & 113 & 366 & 639 & 313 & 560 & 505 & 70 & 0 & 0 & 2619 & 840 \\
\hline 2012 & 0 & 14 & 31 & 282 & 136 & 771 & 644 & 309 & 303 & 385 & 20 & 0 & 2895 & 1068 \\
\hline 2013 & 0 & 0 & 1 & 79 & 566 & 396 & 318 & 326 & 303 & 249 & 0 & 0 & 2238 & 1022 \\
\hline 2014 & 0 & 34 & 16 & 14 & 352 & 859 & 252 & 469 & 284 & 130 & 10 & 0 & 2420 & 950 \\
\hline 2015 & 0 & 0 & 21 & 239 & 132 & 702 & 1192 & 799 & 547 & 303 & 1 & 16 & 3954 & 1066 \\
\hline 2016 & 0 & 49 & 98 & 18 & 322 & 321 & 554 & 433 & 212 & 129 & 82 & 0 & 2218 & 1298 \\
\hline 2017 & 0 & 0 & 83 & 436 & 337 & 1161 & 887 & 641 & 596 & 183 & 10 & 14 & 4349 & 1321 \\
\hline 2018 & 43 & 2 & 15 & 257 & 424 & 1053 & 715 & 334 & 197 & 188 & 3 & 0 & 3231 & 1194 \\
\hline 2019 & 0 & 54 & 34 & 98 & 239 & 331 & 1251 & 340 & 329 & 126 & 69 & 3 & 2874 & 1328 \\
\hline 2020 & 54 & 2 & 0 & 179 & 298 & 310 & 474 & 381 & 390 & 323 & 119 & 0 & 2530 & 930 \\
\hline
\end{tabular}

Rangpur division showed a decreasing trend of annual rainfall except 2010 and 2020. A prolonged drought in the dry season is apparent. The month of May received about half of September, which indicates a long spell drought. Contradictorily, only 2011 enjoyed the year-round shower. The year 2010 and 2016 experienced 04 months long consecutive drought. The division faced 29 months long rainless period during 2010-2020.

Table 3: Monthly rainfall pattern and yield during 2010-2020 in Rangpur division

\begin{tabular}{|c|c|c|c|c|c|c|c|c|c|c|c|c|c|c|}
\hline \multirow[t]{2}{*}{ Year } & \multicolumn{13}{|c|}{ Rainfall (mm) } & \multirow{2}{*}{$\begin{array}{l}\text { Yield } \\
\text { ha/kg }\end{array}$} \\
\hline & Jan & Feb & Mar & Apr & May & Jun & Jul & Aug & Sept & Oct & Nov & Dec & $\Sigma$ & \\
\hline 2010 & 0 & 0 & 0 & 57 & 360 & 903 & 824 & 653 & 469 & 49 & 28 & 0 & 3342 & 900 \\
\hline 2011 & 6 & 11 & 27 & 143 & 290 & 413 & 351 & 470 & 612 & 23 & 9 & 10 & 2365 & 973 \\
\hline 2012 & 4 & 6 & 6 & 147 & 218 & 582 & 1044 & 192 & 717 & 106 & 0 & 0 & 3023 & 1081 \\
\hline 2013 & 18 & 17 & 3 & 39 & 241 & 644 & 1070 & 867 & 295 & 89 & 0 & 0 & 3282 & 1085 \\
\hline 2014 & 4 & 39 & 12 & 11 & 282 & 766 & 425 & 406 & 87 & 0 & 0 & 0 & 2032 & 1314 \\
\hline 2015 & 4 & 26 & 112 & 84 & 152 & 252 & 406 & 650 & 66 & 0 & 0 & 0 & 1753 & 1415 \\
\hline 2016 & 0 & 0 & 48 & 31 & 132 & 713 & 406 & 432 & 533 & 142 & 0 & 0 & 2438 & 1405 \\
\hline 2017 & 6 & 0 & 114 & 84 & 265 & 298 & 130 & 1019 & 105 & 58 & 0 & 0 & 2080 & 1310 \\
\hline 2018 & 0 & 0 & 50 & 94 & 230 & 464 & 638 & 393 & 324 & 3 & 0 & 7 & 2204 & 1329 \\
\hline 2019 & 0 & 18 & 37 & 279 & 147 & 206 & 793 & 95 & 219 & 51 & 0 & 0 & 1845 & 1343 \\
\hline 2020 & 0 & 30 & 15 & 157 & 293 & 722 & 1218 & 220 & 994 & 8 & 0 & 9 & 3668 & 1347 \\
\hline
\end{tabular}

\subsubsection{Relationship between rainfall and yield}

The study revealed that the annual rainfall volume could not influence tea yield. There was a slight negative relationship between average rainfall and yield. In another study, Rahman et al. (2017) found a similar remote negative relationship in the Malnichara tea estate of the Sylhet division during 2012-2017. 
The expected average annual rainfall for the excellent tea leaf production in Bangladesh was 4000-4600 $\mathrm{mm}$ (Ali et al., 2014). Ochieng et al. (2016) revealed that a consistent rainfall pattern is the determinant of high productivity, and any significant deviation affects the production. Wijeratne et al. (2007) reported that very high rainfall reduces sunlight's availability, which turns down photosynthesis. Similarly, excessive rain causes waterlogging conditions, which affects soil saturation and the plant's absorption capacity.

The study area's average rainfall was the lowest in 2011, though the least amount of rain was recorded in 2014. Despite year-round rain in 2011, Sylhet division produced lower but not the least. The division exhibited high resilience in 2014 though it experienced three months-long droughts and the lowest annual rainfall. The respondents from this division argued that they introduced a sprinkler irrigation system in that year to cope with the drought from the very beginning. Resultantly, the national production and the yield of the study area were not the worst hit. In 2010, the division enjoyed year-round rainfall, and it could not predict 03 months prolonged drought in advance. Due to lack of preparedness, not only the study area but also the country produced the least.

Similarly, despite enjoying the highest rainfall in 2017, the maximum production per unit area was in 2019. The Sylhet division gained very balance and even rain distribution this year. Consequently, the national production was the highest in that year though national production represents yield and cropped areas. The Chottogram division, the second-largest tea-producing division, responded similarly as this division faced minimal dryness in that year.

Sylhet and Chottogram division could not maintain their productivity of 2019 in 2020. Sylhet division faced dry December and flooded July. The Chottogram division's yield sharply fell in 2020 due to unusual dryness in February and March. Despite the incremental dry season, the yield is not affected in the Rangpur division as the rainfall distribution does not fluctuate regularly. Only one tea garden, Kazi and Kazi, was taken as a sample from that division, which is the only organic tea garden. The respondents opined that Kazi and Kazi Tea Estate have high resilience capacity, and this tea garden has taken high adaptive measures knowing the distinct micro-climatic pattern. This garden established a modern sprinkler irrigation system. Simultaneously, it uses mulches to conserve soil water and protect the soil from further evaporation. Instead of chemical fertilizer, it adds organic matter to the soil, which has a high water holding capacity. They increased the density of the shade trees to protect scorching. Neem (Azadirachta indica), Basak (Malabar Nut), Bish kanthali (Knotweed), and Nishinda (Chaste Tree) are used as shade trees that are strong repellent against insects and pests. The respondents argued that rainfall distribution could not affect the production of this tea estate.

It is evident that among 03 tea-producing divisions, Sylhet faces occasional flash floods and Rangpur encounters with drought. As a hilly area, the water of the flash flood cannot stand for a long time. On the other hand, the tea gardens' soil texture in this division is sandy loam, which helps in draining out the water very quickly. Neither flash flood nor a short-lived drought can hamper the production of this division significantly. On the flip side, Kazi and Kazi of the Rangpurdivision 
established tea gardens on the flat terrain comprised of sandy loam soil. This tea garden encounters flash floods on rare occasions. Consequently, the management schemes focus only on the predictable drought. Organic farming systems and strong adaptive measures safeguard the production trend in this division. Ironically Chottogram division suffers from unpredictable drought and flash flooding. As a result, the tea growers cannot make dense shade trees to combat drought. The high density of shade trees in case of flooding prolongs the water logging condition. The higher altitude than other divisions cannot help in draining out the water quickly as the soil texture ranges from clayey loam to loam. It can be argued that Chottogram is the only affected tea-producing division due to oscillated rainfall pattern.

Short-spelt rainfall is favourable for tea production, and in contrast, long-spelt rain reduces tea yield (Esham and Garforth, 2013; Duncan et al., 2016). Consistent rainfall patterns can boost up production (Ochieng et al., 2016). Likewise, the tea-producing areas should enjoy a wet and or a combination of the alternative wet and dry seasons. The rainfall pattern and its distribution determine tea's quality (Boehm 2016). Continuous cloud coverage followed by rainfall hinders bush growth and plucking during peak harvesting time (Boehm et al., 2016). The studies showed that the micro-climatic variables became unpredictable, erratic, and extreme for tea production (Dutta, 2014; Marx et al. 2017). The rainfall determines not only the yield but also the quality of the made tea. Heavy rain dilutes the phytochemicals and changes tea's taste, deteriorating the quality (Han et al. 2017).

\subsubsection{Respondents' perception about rainfall distribution and associated problems}

The respondents of the focus group discussions identified several problems originating from rainfall patterns. The tea gardeners from all divisions admitted that they do not receive rainfall in their usual ways. The rain is uneven and does not help the growers. The over-shower in the monsoon cannot help but sometimes creates flood and waterlogging conditions. A minuscule pouring in the dry season, notably from November to February, can boost production. Nighttime rainfall is highly desirable as it does not hamper photosynthesis and plucking. They opined that precipitation occurs in the daytime mainly. It is reported that the soil of the Chottogram divisions shows unpredictable behaviours like rainfall and yield. All tea gardeners from the division said that the soil is deteriorating sharply.

Table 4: Rank of the identified problems in FGDs (Ascending order) 
- Uneven distribution of rainfall in the monsoon

- Circadian heavy continuous pouring in the rainy season, which causes flash floods frequently.

- Scarcity of irrigation water due to lowering of the water table

- Daytime precipitation is more than nighttime
- Very unpredictable and sporadic rainfall throughout the year

- Water scarcity in the dry season and occasional flash floods in the monsoon

- Due to erratic rainfall, the soil cannot maintain its usual characteristics

- Soil is becoming more acidic
- Predictable prolonged drought

- Rare flash flooding

- Unnecessary rain in the rainy season

- Daytime precipitation is more than nighttime

\subsection{Economic impacts of rainfall variability}

\subsubsection{Emergence pests and effect on made tea's quality}

The Chottogram division respondents reported that tea mosquito bugs (Helopeltis Theivora) and Red spider mite (Tetranychus urticae) was minor pest historically. Still, in recent times they have become significant devastating pests. Consequently, they have to go for the frequent foliar spray, which increases production cost and decreases the made tea 'quality. The regular foliar spray may be harmful to consumers in terms of health hazards. Al-Mamun et al. (2016) revealed that the made tea's physiological and biochemical contents are significantly reduced with the increase of infestation of red spider mites. It was recorded that the nymphs and adults of the tea mosquito bugs suck the sap from the tender leaf, bud, and new shoots, which causes low yield. Roy et al. (2015) reported that the insect's salivation and oviposition damage the plant's tissues, resulting in crop loss. Like Chittogram division, these two insects are the primary pests in the Rangpur division. The Kazi \& Kazi tea gardens planted shade trees that have repellent characteristics. Consequently, this organic tea garden has developed resilience and adaptive capacity to respond to the pests' attacks. Climate change decreases the quality and quantity of tea yield by increasing soil erosion, pests' infestations, and outbreaks of diseases (Wijeratne 1996).

Table 5: Emerging pests in different areas

\begin{tabular}{|ll}
\hline Sylhet & Looper Caterpillar, Thrips, Jassid, Crown gall disease \\
\hline Chottogram \& Rangpur & Tea mosquito bug, Red spider mite \\
\hline
\end{tabular}

\subsubsection{Increased/decreased production cost in 2020 associated with rainfall}

Afifa Nagarand Lallakhal tea estate under Sy/het district spent more money in 2020 in purchasing fungicide than in 2019. Record rainfall in July 2020 caused root rot disease in seedlings and younger plants. Lachatoorah tea garden of the same district encountered short-lived drought and moderate insect attacks. Satgaon and Ichamoti tea estate of Moulvibazar district suffered from the scarcity of irrigation water in 2020 due to lowered water table. The gardeners paid more incurred in irrigation. The Surma tea 
garden of Hobiganj district faced slightly higher acidity in 2020 due to a short spell of drought in January 2020. Kodela and Karnafuli of the Chottogram division had to face both drought and short-lived drought. In addition, Kodela experienced a massive attack of tea mosquito bugs and red mites. More expenditure on the Wagachhara tea estate of Rangamati district was associated with increasing soil pH and weed control. Kazi \& Kazi spent huge money to go for organic farming in the initial stage. It did not pay any additional money in 2020.

Table 6: Extra cost involved to cope with rainfall variation

\begin{tabular}{lllllll} 
Tea gardens & Weedicide & Insecticide & Fungicide & Irrigation & Dolomite & Total \\
\hline Afifa Nagar & 0 & 0 & 1200 & 0 & 0 & 1200 \\
\hline Lallakhal & 0 & 0 & 1400 & 0 & 0 & 1400 \\
\hline Lachatoorah & 0 & 800 & 0 & 2200 & 0 & 3000 \\
\hline Surma & 0 & 0 & 0 & 0 & 800 & 800 \\
\hline Satgaon & 0 & 0 & 0 & 4000 & 1200 & 5200 \\
\hline Ichamoti & 0 & 0 & 0 & 3600 & 800 & 4400 \\
\hline Karnafuli & 0 & 0 & 1300 & 2600 & 0 & 3900 \\
\hline Kodela & 0 & 1200 & 1300 & 3600 & 0 & 6100 \\
\hline Wagachhara & 500 & 0 & 0 & 0 & 600 & 1100 \\
\hline Kazi \& Kazi & 0 & 0 & 0 & 0 & 0 & 0 \\
\hline Mean & 50 & 200 & 520 & 1600 & 340 & 2710
\end{tabular}

\subsubsection{Profit/loss analysis}

The profit/loss was calculated for the year 2020 based on data provided during focus group discussions. In 2020, the gardeners pegged massive revenue loss due to mainly pandemic corona 19. Also, the pandemic corona 19 played a crucial role in surging the cost of production and decreasing the market price due to lower consumption. The loss was exaggerated by rainfall-related factors (Table 7). According to respondents' perceptions, the production cost depends on the overhead expenditure, type of ownership, branding, quality of the products, nature of employees, bargaining capacity with the brokers and buyers, and management. Out of the ten tea gardens, Satgaon, Ichamoti, and Kodela tea gardens experience continued loss. Satgaon and Ichamoti continuously encounter the lower water table. On the other hand, the Kodela tea garden simultaneously faces uneven rainfall and the emergence of devastating pests. Surma and Kazi \& Kazi are running without any losses. Waggachara tea estate can minimize the loss as their permanent employees are the minimum. This family-run tea garden does not employ any managerial level staff. Consequently, its overhead cost is nearly zero. The gardeners surmised that rainfall affects the quality and production cost. In the continuous heavy rain, the permanent workers 
cannot work, but they are paid. The moisture contents of the leaf increase, and consequently, the drying cost increases. Contrastingly, in case of prolonged drought, the leaf becomes scorched.

Table 7: Profit/loss of the gardeners for the year 2020

\begin{tabular}{|llll|}
\hline & $\begin{array}{l}\text { Production } \\
\text { cost (BDT)/kg }\end{array}$ & $\begin{array}{l}\text { Sell } \\
(\mathrm{BDT}) / \mathrm{kg}\end{array}$ & $\begin{array}{l}\text { Profit (+)/ } \\
\text { Loss }(-) / \mathrm{kg}\end{array}$ \\
\hline Satgaon & 200 & 195 & -5 \\
\hline Ichamoti & 200 & 177 & -23 \\
\hline Lackatoorah & 165 & 142 & -23 \\
\hline Afifa Nagar & 200 & 185 & -15 \\
\hline Lallakhal & 208 & 184 & -24 \\
\hline Surma & 165 & 192 & +27 \\
\hline Telipara & 180 & 165 & -15 \\
\hline Kornafuli & 220 & 220 & 0 \\
\hline Kodala & 230 & 210 & -20 \\
\hline Kazi and Kazi & 240 & 240 & 0 \\
\hline Waggachara & 204 & 185 & -19 \\
\hline Average & 201.1 & 190.5 & -10.6 \\
\hline
\end{tabular}

\subsection{Social impact}

\subsubsection{Reduced income}

The workers are categorized as temporary (contractual) and permanent. They are mainly responsible for seedling plantation, leaf plucking, foliar spraying, withering, weeding, cleaning, transporting, cleaning, spraying pesticide, and other intercultural operations. A worker's task is defined by the plucking of 18-24 $\mathrm{kg}$ of leaves per day at the cost of 120 Bangladesh Taka. A portion of this wage is deducted to add provident and religious funds and the union membership fee. Besides, the workers enjoy five kilograms of rice or flour as a ration meal per week, free housing, and medical care from the owners. To avail these facilities a worker must work 05 days in a week. A worker gets 4.5 takas for plucking one kg of the leaf as overtime work out of a task. It is revealed that a worker earned 120-450 taka per day, counting overtime work. The average daily income was 240 takas/worker/day in 2019, which decreased to 224 takas in 2020 (Table 8). The workers reported that they could not pluck leaves beyond their tasks in extreme weather and henceforth low yield.

Table 8: Average daily wage of a permanent worker in 2019 and 2020 


\begin{tabular}{clll} 
Year & \multicolumn{2}{l}{ Range } & Average \\
\cline { 2 - 3 } & Min & Max & \\
\hline 2019 & 120 & 450 & 240 \\
\hline 2020 & 120 & 430 & 224
\end{tabular}

\subsubsection{Job loss}

The study found that $77 \%$ were permanent the rest was temporary or contractual (Figure 8). Hossain et al. (2017) reported that $70.6 \%$ of workforces were employed permanently, while $29.4 \%$ were used contractually. The respondents opined the employment of temporary workers depends on yield, cost of production, and profit.

Usually, the temporary or contractual workers are employed during peak plucking season (May-October). In 2019, the temporary worker's average working months was 4.42, which fell off to 3.17 in 2020 (Figure 9). The employment generation and daily income depend on climatic variables like rainfall. The gardeners try to minimize the cost of production in low yield due to climatic variables by contracting the contractual workers' job market. Similarly, the overtime work of the permanent workers is hampered. The Kazi \& Kazi is exceptional as this company runs organic dairy farming along with tea production. Huge cow dung is required for organic fertilizer and for producing biogas. This company has brand organic milk products. The garden owners provide loans to the workers for purchasing dairy cattle, and the workers pay back the loan by selling milk and cow dung at market price. Consequently, their income does not depend on tea leaf plucking only. The workers of this tea estate have enriched their livelihoods.

\subsubsection{Irregularity in wage payment}

Irregularity in wage payments was reported in low yield and increased cost of production due to climatic variability. Sometimes, it is tough to pay the workers on the weekend regularly. $79.6 \%$ opined that the garden owners could not pay them every weekend due to a shortage of money flow among the permanent workers. By considering the living expenses, periodic payment causes extra challenges in maintaining a decent livelihood. The workers of Kazi \& Kazi do not encounter such problems.

\subsubsection{Inconvenient paying back of provident fund}

The permanent workers deposit $7.5 \%$ of basic pay as the provident fund started at 18 years old and ended at 60 years of age. At the time of retirement, they receive double the deposited money plus the bank's interest rate. The respondents except Kazi \& Kazi opined that the gardeners could not repay the provident fund timely in production loss.

\subsection{Extra-climatic problems}

\subsubsection{Profit-making by the intermediaries}


The tea gardeners argued that with lower domestic consumption due to corona and lower sell price, the retailer price was steady. The producers were highly affected, and the consumers did not pay less money in purchasing packed tea. The intermediaries, notably buyers, secured the highest return (Table 9). In addition, they have to pay transportation costs to carry the made tea to the warehouses. They have to pay $01 \%$ commission to the brokers and $01 \%$ of the selling price as cess to the government. The brokers also get a $01 \%$ commission from the buyers. In total, they earn $02 \%$ of the producer's sell price without any investment. The buyers have to pay $15 \%$ of the producer's sell price. By purchasing made tea from different gardens, they grade and blend mixed tea. Finally, the tea is dressed with the new packet in the name of buyers. The buyers' expenditures are also associated with advertisement, marketing, and transportation. The wholesaler buys from the buyers and stores in their godowns. The retailers' prices highly fluctuate as it depends on consumers' bargaining capacity. The respondents argued that the buyers exploited three cases: high production, heavy rainfall, and lower consumption. In the chance of high rain, they reduce the producers' price in the name of high moisture content. In anticipation of increased production and lower consumption, they sharply contract the price mentioning the demand and supply relationship. It was also reported that few buyers are highly united and syndicated, and they determine the fate of the producers (Rahman $a, b, c, d, e, f$ ).

Table 9: Profit/loss of the market players 
Items

Mean

(BDT)

Producer Expenditure (production cost, transportation, warehouse charge. Broker's 196.9 cost, and cess)

Sell

186.7

Loss

10.2

Broker

Expenditure

0

Profit

3.74

Warehouse Expenditure (maintenance)

0.94

Profit

2.8

Buyer

Buy

186.7

Expenditure

70

(VAT, Broker's commission, grading, blending, processing, packaging, transportation)

Sell

300

Profit

43.3

Wholesaler Buy 300

Expenditure (Transportation, storage)

Sell

325

Profit

13

Retailer

Buy

325

Transportation

7

Sell

Profit

18

Consumer

Buy

350

\subsubsection{Other regulatory problems}

Bangladesh Tea Board (BTB) is an autonomous body responsible for drafting laws, rules, and public policies regarding tea production and the management of the tea sector. The gardeners believe that BTB always upholds the buyers' interests and rarely cares about the producers' welfare. The buyers have benefitted from the existing regulatory framework. Other farmers buy agricultural inputs like fertilizers, pesticides, and machinery at a subsidized rate, except the tea growers. On the other hand, the rest agricultural sectors pay electricity charges for irrigation purposes at a household rate, but the tea growers 
are charged with a high commercial rate. The government helps the farmers in various ways and provides various incentives to boost up agricultural production. Contrarily, the government imposes $1 \%$ cess and $15 \%$ VAT on the tea products despite being an agricultural crop.

\section{What To Do?}

Following Kazi \& Kazi model: Kazi \& Kazi, the only organic tea garden of Bangladesh, has developed a highly resilient farming system against any adverse effect of climatic variables like drought. As it produces premium quality organic tea, it makes a profit under any circumstances. It has developed associated organic dairy entrepreneurship, which boosted the workers' socio-economic conditions and the company. The other tea estates can follow organic farming to avoid gradual tea production loss and improve the workers' living standards. On the other hand, this is essential for ensuring pure, safe, and health hazard beverages. Albizia odoratissima, A. Chinensis, and A. lebbek are commonly used in other tea gardens among the shade trees. These shade trees should be gradually replaced by Neem (Azadirachta indica), Basak (Malabar Nut), Bish kanthali (Knotweed), and Nishinda (Chaste Tree) to combat emerging pests.

Considering tea as an agricultural crop: Like other crops, tea growers should enjoy government subsidies in purchasing agricultural inputs, including fertilizers, pesticides, electricity, and different types of machinery. Government should exclude this sector from paying cess money and VAT. This stimulus will help the growers to restore their confidence level and to minimize the losses.

Clearing intermediaries from the market chain: According to the growers' perception, the intermediaries' incremental hegemony in the market chain is causing more problems than climate change. Neither the head (the growers) nor the tail (the consumers) is benefitted from the existing market systems. Most of the growers face loss in most of the years, but the intermediaries, notably the buyers, make huge profits. SDG target 2.b. stresses on correcting the market chain and clearing all obstacles to ensure food security. Therefore, it is recommended that the government intervene to remove those intermediaries from the market chain or limit their profits to save both producers and consumers.

Crop insurance: Tea producers should be obliged to bring under the umbrella of risk insurance to transfer the production loss into monetary compensations.

Integrated adaptive measures: The drainage and irrigation systems should be modernized to protect the plants from waterlogging and drought, respectively. Establishing a sprinkler irrigation system may ensure efficient water resources use and minimize the adverse effect of drought. Applications of indigenous knowledge can be encouraged. Bangladesh Tea Research Institute should work intensively to develop drought-resistant varieties. Integrated nutrient management can combat nutrient deficiency and drought simultaneously. The pruning litter and shade tree droppings should be preserved and added to the soil to increase the soil's organic matter and water holding capacity. 
Worker's floor protection: The workers should be considered part of society's mainstream and left-behind group. The government should incorporate them into all safety net programs administered by various public departments. Only the tea growers cannot ensure their wellness and meet basic needs. Besides, the government can encourage local, national, and international Non-Government Organizations to improve the workers' socio-economic conditions.

\section{Conclusions}

The tea sector of Bangladesh has multidimensional importance in earning foreign currency, employment generations, food security, green coverage, sustainable land use, and biodiversity conservation. The land of most of the tea gardens is Khas (government-owned land) in nature. Each garden is a chunk of land which the government can use for many purposes. If the tea plantation is stopped, the land is grabbed overnight. On the other hand, Bangladesh's natural forest habitats have become lost, degraded, and fragmented, creating remnants. Consequently, the tea gardens are gradually being turned into wildlife sanctuary. Therefore, this sector should be survived at least, for nature conservation. This study used a dataset of monthly rainfall, which is only available in the tea gardens. The data on various climatic variables should be recorded to understand to assess the impacts of multiple stressors. Future research should focus on the causal factors of emerging new pests and the remedies avoiding chemical pesticides to ensure safe and pure beverages. Bangladesh may witness more extreme climate events in the future. The profitable tea sector is interconnected with achieving many goals of SDGs. It reduces poverty (SDG 1), ensures food security (SDG 2), and creates decent jobs (SDG 8). The women workers have established equal rights to financial resources (SDG 5). The green coverage helps in maintaining a carbon footprint. SDG 15 urges to protect biodiversity, notably the rare species, which tea gardens do. Simultaneously, SDG 13 advocates for the actions to cope with climate change. Target-1.5 of SDGs draws attention to building a resilient society to absorb climatic shocks. Hence, the tea sector warrants policy initiatives to achieve SDGs. The tea should enjoy government stimulus like other crops. On the other hand, the policy should be producer and consumer-friendly. The obstacles should be cleared to protect the gardens from the adverse effect of climatic events and to ensure the welfare of the growers and workers.

\section{Declarations}

Conflict of interests: The author declares is no conflict of interests or conflicting issues in this research paper.

Fund: This research was funded by Bangladesh Public Administration Training Centre.

\section{References}

Adjei-Mensah, K., Kusimi, J.M. Dwindling water supply and its socio-economic impact in Sekyere Kumawu District in Ashanti Region of Ghana: public opinion on the role of climate change. GeoJournal 85, 1355-1372 (2020). https://doi.org/10.1007/s10708-019-10026-0. 
Ahmed S. et al. (2018) Global Climate Change, Ecological Stress, and Tea Production. In: Han WY., Li X., Ahammed G. (eds) Stress Physiology of Tea in the Face of Climate Change. Springer, Singapore. https://doi.org/10.1007/978-981-13-2140-5_1.

Ali, M, Uddin, MN, Mobin, MN \& Saha, N 2014 'Effects of Microclimatic Parameter on Tea Leaf Production in Different Tea Estates, Bangladesh', Journal of Environmental Science and Natural Resources, vol. 7, no. 1, pp. 183-188.

Al-Mamun, M. S. ; Hoque, M. M. ; Mainuddin Ahmed ; Md. Yasin (2016) Physiological and Biochemical Changes in Tea Leaves and Made Tea Due to Red Spider Mite Infestation. Asian Journal of Plant Sciences, 15: 16-25.

Basher, M., Stiller-Reeve, M.A., Saiful Islam, A.K.M. et al. Assessing climatic trends of extreme rainfall indices over northeast Bangladesh. Theor Appl Climatol 134, 441-452 (2018). https://doi.org/10.1007/s00704-017-2285-4.

Berkhout, F, Hertin, J and Jordan, A (2002) Socio-economic futures in climate change impact assessment: using scenarios as 'learning machines',Global Environmental Change, Vol. 12, No. 2,pp. 8395.

Boehm, R, Cash, SB, Anderson, BT, Ahmed, S, Griffin, TS, Robbat, A, Stepp, JR, Han, WY, Hazel, M \& Orians, CM 2016 'Association between empirically estimated monsoon dynamics and other weather factors and historical tea yields in China: Results from a yield response model', Climate, vol. 4, pp. 20.

BTB 2021, Monthly Bulletin of Statistics on tea. January 2021. Bangladesh Tea Board, Nasirabad, Chittagong.

Cai, XM, Sun, XLL, Dong, WXX, Wang, GCC \& Chen, ZMM 2013 'Herbivore species, infestation time, and herbivore density affect induced volatiles in tea plants', Chemoecology, vol. 24, pp. 1-14.

Chang, K and Brattlof, M. (2015). Socio-economic implications of climate change for tea producing countries, Market and Policy Analyses of Raw Materials, Horticulture and Tropical (RAMHOT) Products Team, Food and Agriculture Organization of the United Nations (FAO).

Cheruiyot, EK, Mumera, LM, Ng'Etich, WK, Hassanali, A, \& Wachira, F 2010 'High fertilizer rates increase susceptibility of tea to water stress', Journal of Plant Nutritio,. vol. 33, pp. 115-129.

Duncan, JMA, Saikia, SD, Gupta, N \& Biggs, EM 2016 'Observing climate impacts on tea yield in Assam, India' Applied Geography, vol. 77, pp. 64-71.

Dutta, R 2014 'Climate change and its impact on tea in Northeast India', Journal of Water and Climate Change, vol. 5, no. 4, pp. 625-632. 
Eric, RS, Li, X, Kfoury, N, Morimoto, J, Han, WY, Ahmed, S, Sean, BC, Griffin, TS, Stepp, JR, Robbat \& Orians, CM 2019 'Interactive effects of drought severity and simulated herbivory on tea (Camellia sinensis) volatile and non-volatile metabolites', Environmental and Experimental Botany, vol. 157, pp. 283-292.

Ericksen N.J., Ahmad Q.K., Chowdhury A.R. (1996) Socio-economic Implications of Climate Change for Bangladesh. In: Warrick R.A., Ahmad Q.K. (eds) The Implications of Climate and Sea-Level Change for Bangladesh. Springer, Dordrecht. https://doi.org/10.1007/978-94-009-0241-1_5

Esham, M \& Garforth, C 2013 'Climate change and agricultural adaptation in Sri Lanka: A review', Climate and Development, vol. 5, pp 66-76.

Han, WY, Huang, JG, Li, X, Li, ZX, Ahammed, GJ, Yan, P \& Stepp, JR 2017 'Altitudinal effects on the quality of green tea in east China: a climate change perspective', European Food Research Technology, vol. 243, pp. 323-330.

Hossain, SMS, Khan, AR, Islam, MZ and Khandaker, S (2017), Socio-economic situational analysis of tea plantation workers: a case study from Lubachhara Tea Garden, Sylhet, Bangladesh Journal of Public Administration, vol. 25, no. 2, pp. 75-83

Islam M.N., Tamanna S., Rahman M.M., Ali M.A., Mia I. (2021) Climatic and Environmental Challenges of Tea Cultivation at Sylhet Area in Bangladesh. In: Jakariya M., Islam M.N. (eds) Climate Change in Bangladesh. Springer Climate. Springer, Cham. https://doi.org/10.1007/978-3-030-75825-7_6

ITC 2015, Annual Bulletin of Statistics (September 2015), International Tea Committee (ITC), London, UK, p. 158.

Kfoury, N, Morimoto, J, Kern, A, Scott, ER, Orians, CM, Ahmed, S, Griffin, T, Cash, SB, Stepp, JR, Xue, D, Long, C \& Robbat, A 2018 'Striking changes in tea metabolites due to elevational effects', Food Chemistry, vol. 264, pp. 334-341.

Marx, W, Haunschild, R, Bornmann, L 2017 'Global warming and tea production-the bibliometric view on a newly emerging research topic', Climate, vol. 5, no. 3, pp. 46.

Matsumoto,K (2019) Climate change impacts on socio-economic activities through labor productivity changes considering interactions between socio-economic and climate systems, Journal of Cleaner Production,216:528-541.'

Mishra, A et al. 2019 'Adaptation to Climate Change in the Hindu Kush Himalaya: Stronger Action Urgently Needed', in: Wester, P, Mishra, A, Mukherji. A, \& Shrestha, A. (eds) The Hindu Kush Himalaya Assessment, Springer, Cham.

Mojid, M, Rannu, R, \& Karim, N 2015 'Climate change impacts on reference crop evapotranspiration in North-West hydrological region of Bangladesh', International Journal of Climatology, vol. 35, pp. 4041- 
4046.

Niinemets, Ü 2015 'Uncovering the hidden facets of drought stress: secondary metabolites make the difference', Tree Physiology, vol. 36, pp. 129-132.

Ochieng, J, Kirimi, L, \& Mathnge, M 2016 'Effects of Climate variability and change on agriculture production: The case of small scale farming in Kenya', NJAS-Wagenngen Journal of life Science, vol. 77, pp. 71-78.

Qiao,Y. Niels, Halberg, Saminathan V. and Steffanie, S. (2018). Assessing the social and economic benefits of organic and fair trade tea production for small-scale farmers in Asia: a comparative case study of China and Sri Lanka, Journal of Renewable Agriculture and Food Systems, Vol.2, Nos. 12. China, pp1- 12 doi:10.1017/S1742170515000162.

Rahman, M. R., Islam, N. Hossain, R. Ali, M. A. (2017). Statistical Association between TemperatureRainfall and Tea Yield at Sylhet Malnicherra Tea Estate: An Empirical Analysis, The Jahangirnagar Review, Part II, Social Sciences, Vol. XLI: 1-13.

Rahman, M.M. (2021a). The rhetorical blue economy in Bangladesh: Analyzing the inborn regulatory bottlenecks, Acta Aquatica: Aquatic Sciences Journal, 8 (2): 66-73.

Rahman, M.M. (2021b), Achieving Sustainable Development Goals of Agenda 2030 in Bangladesh: the crossroad of the governance and performance, Public Administration and Policy: An Asia-Pacific Journal, 24 (2): 195-211. https://doi.org/10.1108/PAP-12-2020-0056

Rahman, M.M. (2021c) Biologia Futura: can co-management protect Saint Martin's corals of Bangladesh? BIOLOGIA FUTURA 72, 517-527. https://doi.org/10.1007/s42977-021-00101-4

Rahman MM (2021d) Effectiveness of the coastal and marine conservation initiatives in Bangladesh: Analyzing the drawbacks of the legal, policy, and institutional framework. Journal of the Indian Ocean Region (forthcoming).

Rahman MM (2021e) Regulatory Framework of Small-Scale Fishers in Bangladesh: Safeguard or Jeopardy? In: Chuendagdee, R (ed.) Visualizing Small-scale Fisheries of Bangladesh, Too Big To Ignore (TBTI), Canada, http://dx.doi.org/10.2139/ssrn.3939730

Rahman MM (2021f) Analyzing the institutional and regulatory framework for operationalizing the blue economy in Bangladesh: Lessons from Australia, 13 December 2021, PREPRINT, Research Square, https://doi.org/10.21203/rs.3.rs-1163138/v1

Roy M (2013). Time Series, Factors and Impacts Analysis of Rainfall in North-Eastern Part in Bangladesh, International Journal of Scientific and Research Publications, Volume 3, Issue 8, 1 ISSN 2250-3153.UK. 
Roy, S., Muraleedharan, N., Mukhopadhyay, A. \& Handique, G. (2015) The tea mosquito bug, Helopeltis theivora Waterhouse (Heteroptera: Miridae): its status, biology, ecology and management in tea plantations, International Journal of Pest Management, 61:3, 179-197, DOI:

10.1080/09670874.2015.1030002.

Statistica (2021) Production of tea by main producing countries since 2006. Url:

https://www.statista.com/statistics/264188/production-of-tea-by-main-producing-countries-since-2006/

Wijeratne, MA, Anandacoomaraswamy, A, Amarathunga, MKSLD, Ratnasiri, J, Basnayake BRSB \& Kalra, N 2007 'Assessment of impact of climate change on productivity of tea (Camellia sinensis L.) plantations in Sri Lanka', Journal of the National Science Foundation of Sri Lanka, vol. 35, pp. 119-126.

Wijeratne, M.A. Vulnerability of Sri Lanka tea production to global climate change. Water Air Soil Pollut 92, 87-94 (1996). https://doi.org/10.1007/BF00175555.

\section{Figures}

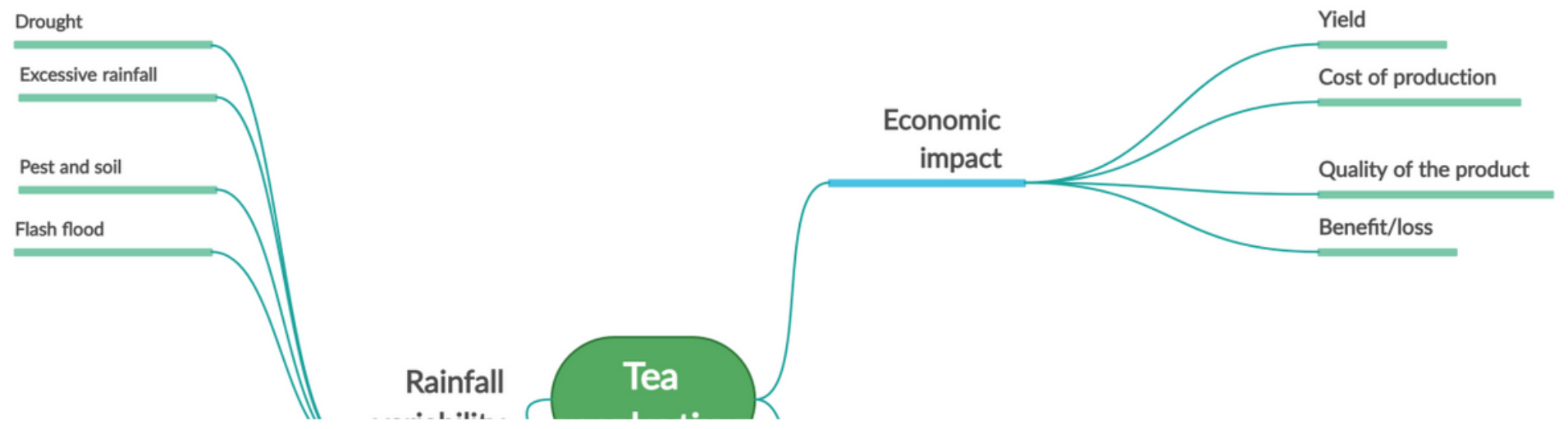

\section{Figure 1}

$<p>$ Conceptual framework of the study $</ p>$ 
Literature review to develop conceptual framework and the focused areas

\section{Assessing the trend of rainfall and tea yield by secondary time series data}

\section{Relating annual rainfall and yield through Pearson Correlation Coefficient}

Other economic impact assessment utilizing time series data and fresh primary data collected through FEDs

\section{Assessing Social impact through personal interviews}

\section{Assessing extra-climatic problems through FGDs and workshop}

Figure 2

$<\mathrm{p}>$ Methodological framework $</ \mathrm{p}>$

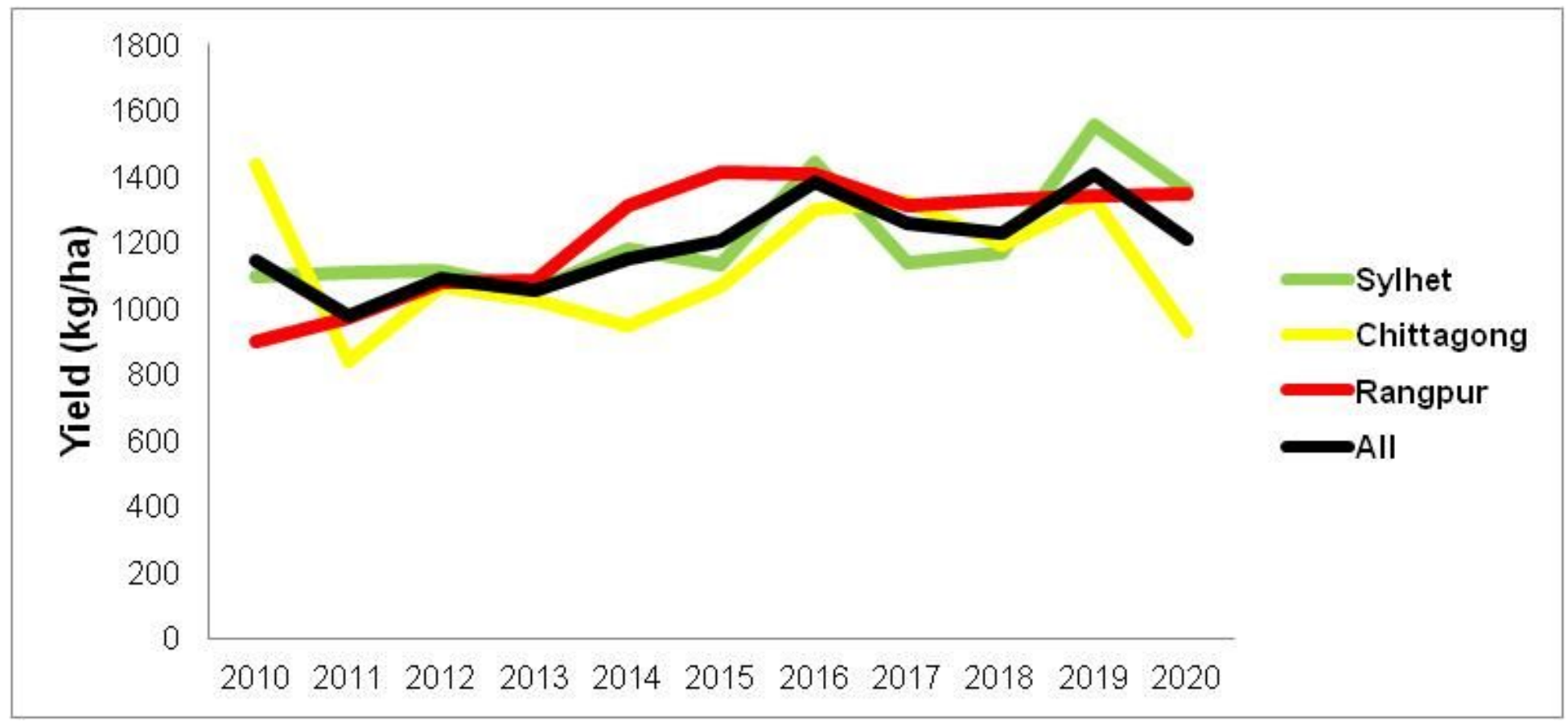

\section{Figure 3}

$\langle p>$ Trend of annual rainfall and tea yield in the study area $</ p>$ 


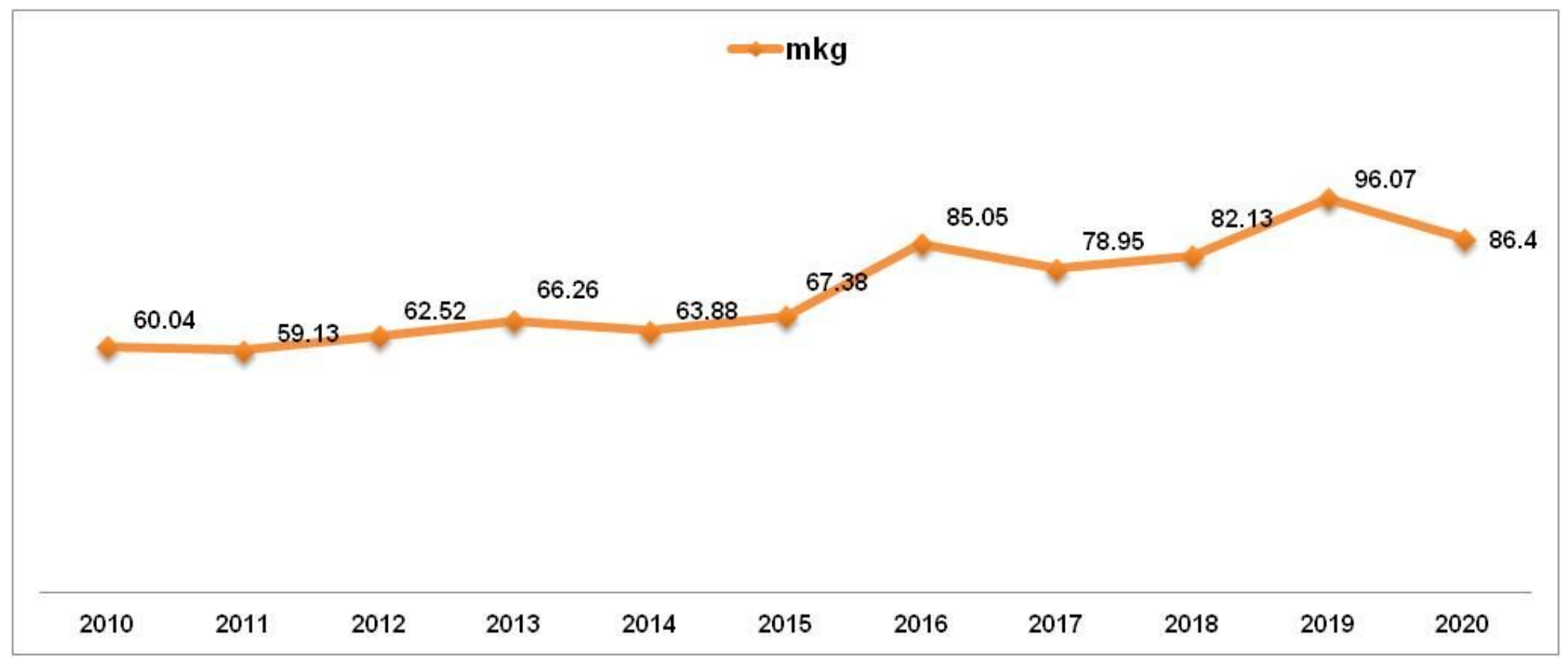

\section{Figure 4}

$<p>$ National production trend yearly $</ p>$ 


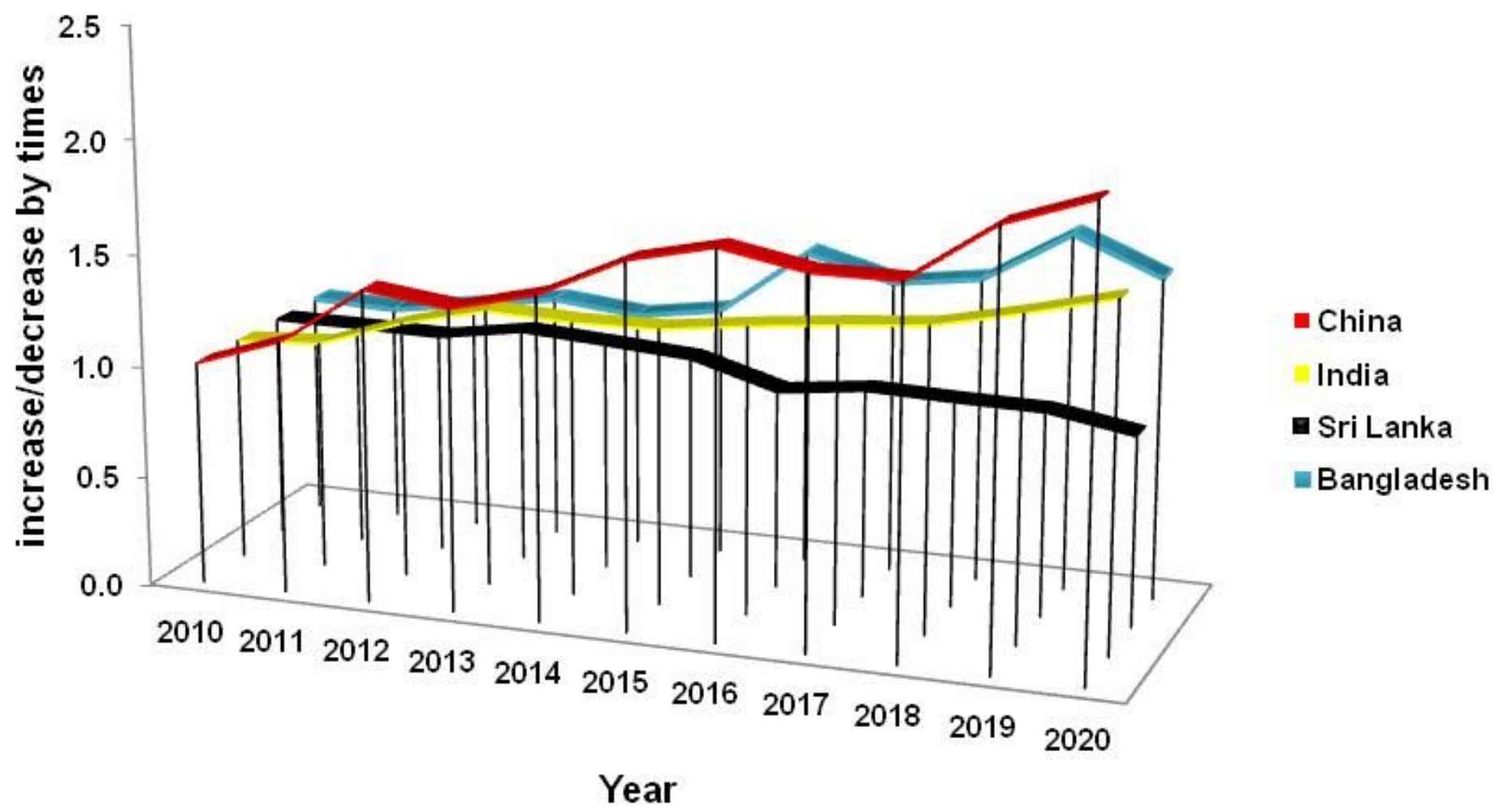

Figure 5

$<p>$ Annual production trend of major producing countries of Asia $</ p>$ 


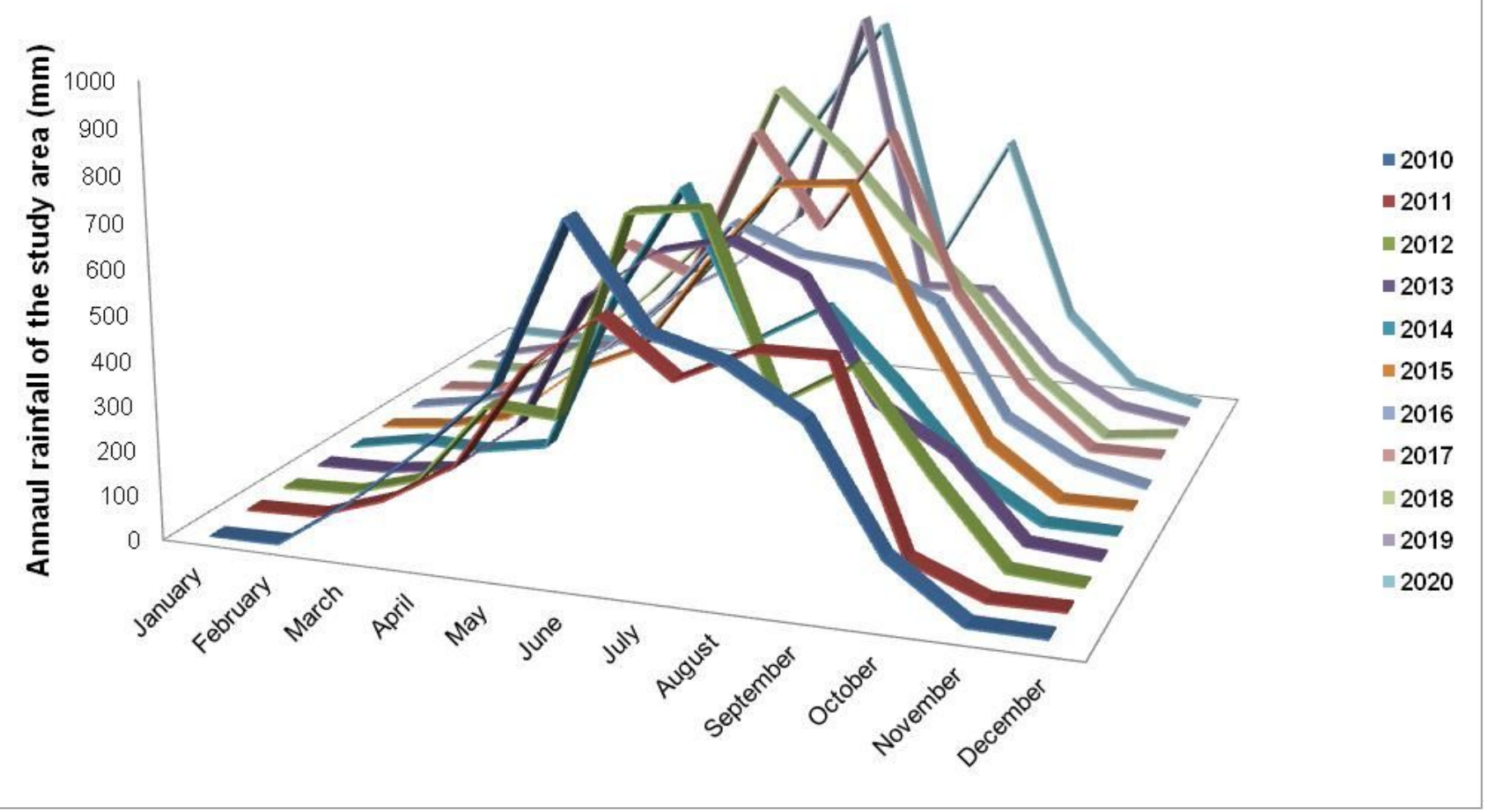

Figure 6

$<p>$ Monthly rainfall pattern during $2010-2020</ p>$ 


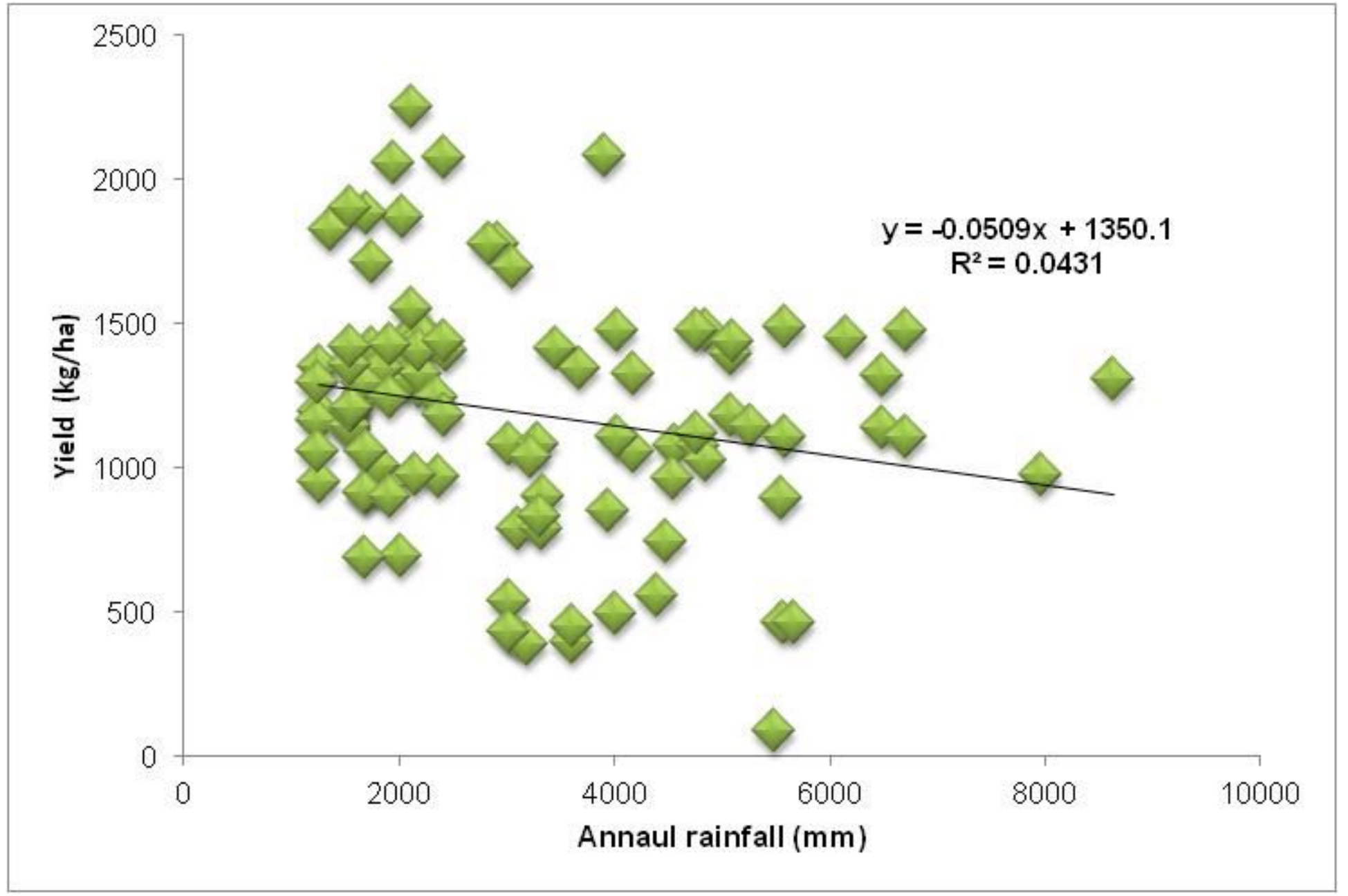

Figure 7

$<p>$ Relationship between average annual yield and annual rainfall of 10 tea gardens $</ p>$

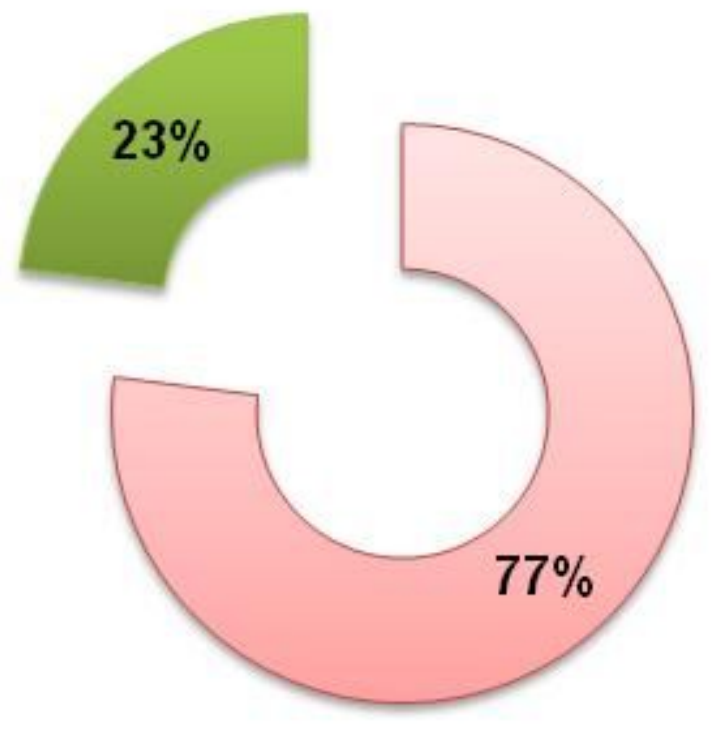

$\square$ Permanent

- Temporary 
Figure 8

$\langle p>$ Permanent and temporary worker's ratio $</ p>$

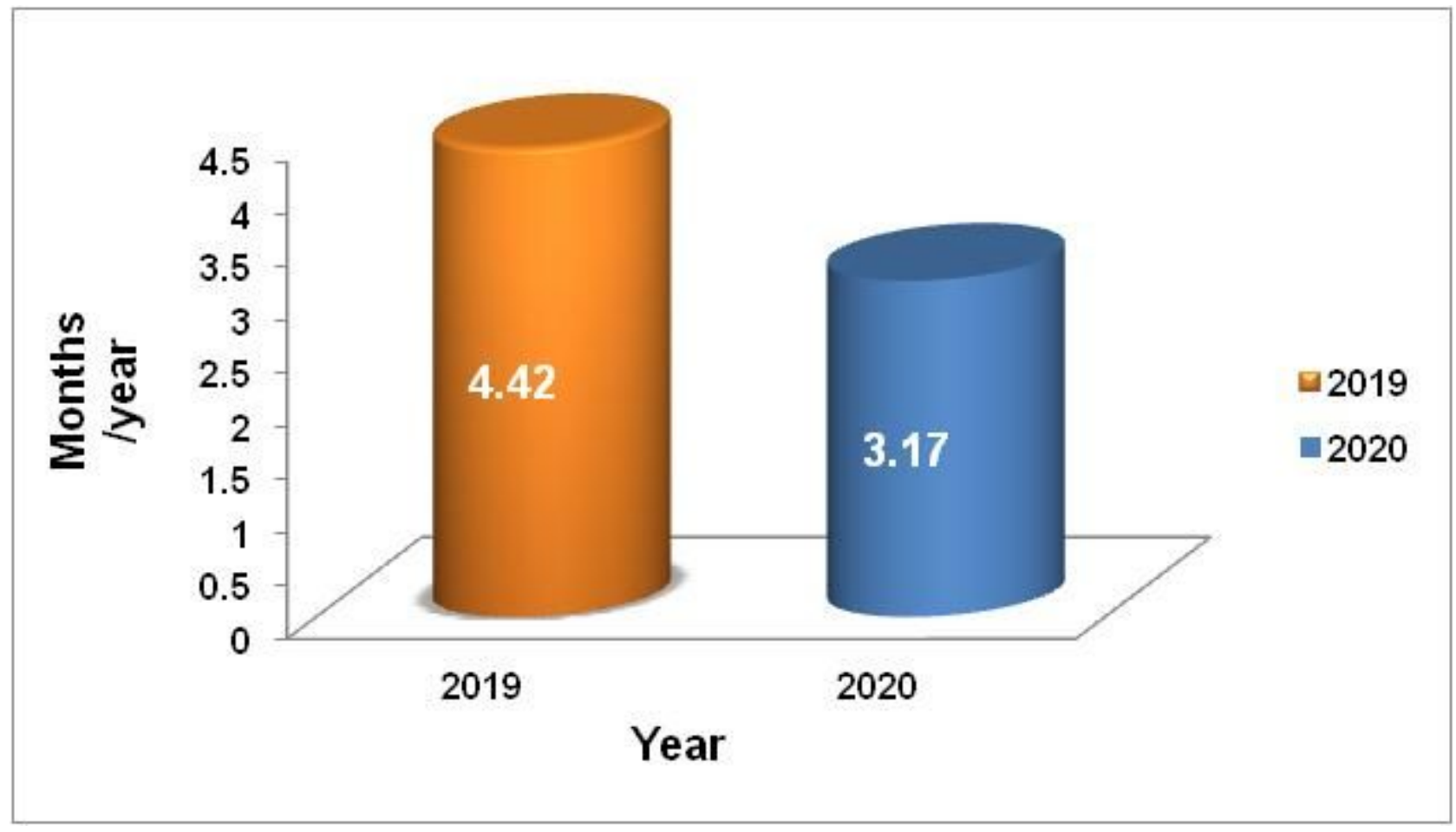

Figure 9

$<p>$ Months of employment of the temporary workers in 2019 and $2020</ p>$

\section{Commercial rate of agricultural inputs, including electricity}

Biased Bangladesh Tea Board

Figure 10 
$<p>$ Regulatory problems $</ p>$

Page 28/28 